\title{
The Identification of Teachers' Ability of the Fourth Grade Students in Implementing Thematic Learning in Curriculum 2013 in SD N. 4 Banyuasri
}

\author{
Putra, Kadek Ashadi \\ Ganesha University of Education \\ ashadiputra813@gmail.com
}

\begin{abstract}
This study was conducted to identify the ability of IV grade teacher of implementation of Curriculum 2013 in SD No. 4 Banyuasri in the academic year of 2013/2014 viewed from lesson planning, learning implementation, and learning assessment implementation. This study included as a qualitative descriptive study. The subjects of this study were thematic teachers at SD No. 4 Banyuasri, lesson planning, and assessment paper. The objects of this study were teacher's ability of implementation of Curriculum 2013 in SD No. 4 Banyuasri viewed from lesson planning, learning implementation, and learning assessment implementation. The data collecting method of this study were observation, interview, and documentation. The obtained data were in the form of qualitative data (interview transcript and documentation) also of value variables of lesson planning, learning implementation, and learning assessment implementation. The data were analyzed by statistic descriptively. The result of analysis showed that the lesson planning who designing by IV grade Thematic teachers at SD No. 4 Banyuasri was qualified very good with an average value of 24 (of maximal total value 24). Learning implementation was qualified good with an average value of 51 (of maximal total value 68). The learning assessment implementation was qualified good with an average value of 11 (of maximal total value 16).
\end{abstract}

Keywords: Curriculum 2013, learning assesment implementation, learning

\section{Introduction}

The realization as Indonesian human with high quality and high competitiveness cannot be separated to the quality of education. This is due to because education is a conscious effort. It can be developed by human through a learning process that will determine the development of individual education and community development (Sanjaya, 2005: 17). The improvement of Indonesian human resources quality must be accompanied by the quality of education development. In addition, achievement of the quality education objectives is strongly influenced by the curriculum. The curriculum has a central position in the whole process of education. Curriculum according to Nasution (2006: 5) is a plan drawn up to launch the process of learning under the guidance and responsibility of the school or educational institution and its faculty. This is in line with the understanding of curriculum contained in the national education system law article 1 point 19 No. 20 in 2003, that is stated that curriculum is a set of plans, and setting the objectives, content and learning materials and the way that is used to guide the implementation of learning activities in achieving the education goals (in Kurinasih, 2014). The curriculum quality will affect the improvement of human resources quality in order to compete in the global competition, the development of science and technology (Science and Technology), and finally they have the skills in their life

After the independence of the Republic of Indonesia, the curriculum has encountered several improvements. Completion of the curriculum were grouped by three groups namely curriculum lesson plans, curriculum-based objectives, and competency-oriented curriculum. Kurniasih (2014) mentions lesson plan curriculum was applied from 1947 to 1968 consisting of the curriculum in 1947 (Lesson Plan, 1947), curriculum 1952 lesson plan in 1952, lesson plan 1964 and 1968. The curriculum of objective oriented was applied from 1975 to 1994 consisting of the curriculum 1975, curriculum 1984, and curriculum 1994. The curriculum that was applied after the 1994 was competency-based curriculum (KBK) in 2004 and continued by school based curriculum (SBC), and then the government is currently developing a curriculum back to the curriculum of 2013. The development of the curriculum is done by the government in order to develop the education system (Kurniasih, 2014). In fact each curriculum must have weaknesses and need to be evaluated and repaired in order to achieve education objectives. 
The Government through the Education and Culture Ministry (Kemendikbud) has made improvements as a revision of the school based curriculum named Curriculum 2013. This curriculum is enforced starting in the academic year 2013/2014 and gradually implemented until 2015.

The government revealed that the curriculum is not a new curriculum in 2013, but it is a development of the previous curriculum (SBC). Permendikbud number 65 year 2013 about the Standard Process of Primary and Secondary school states that the principle of learning changes the partial learning towards an integrated learning. Curriculum 2013 emphasizes personal experience through the process of observing, asking, reasoning and trying (observation based learning) to improve the creativity of learners, as well as the necessity of directing the learning process to Attitude, Skill, Knowledge (ASK). Furthermore, Kurniasih (2014) reported that the improvement also occurred in learning approach from teacher-centered learning to students centered learning, from passive learning to active learning-exploring, from one way communication to two way communication, from independent learning to group work learning.

Although there were pro and contra at the beginning of its implementation, the government insists to continue to implement Curriculum 2013 in order to improve the quality of Indonesia education in the future. But the implementation of that curriculum must be dismissed because of various problems. Curriculum termination decision is taken by Anies Baswedan as the Minister of Education based on the recommendation of the evaluation team headed by professor of Yogyakarta State University (UNY) Suyanto. However the termination of curriculum 2013 did not involve the entire school. For schools that have implemented the curriculum 2013 for three-semester or the school that already applied the curriculum 2013 before it is simultaneously carried out will be given the opportunity to apply the curriculum 2013. It is because there must be a tester which is used to show the enhancement of the curriculum in 2013.

The indicator of the Curriculum 2013 termination was unprepared teachers and the difficulties to change teachers' mindset from KTSP curriculum to Curriculum 2013 (Kurniasih, 2014). It is happened especially in the education units as the institution that organizes the learning process and teachers as a leader in the implementation of the curriculum that directly deal with learners and as key organization of learning in the classroom. The successful implementation of a new curriculum is determined by the teacher. According to teachers and lecturers Law no. 14 year 2005 point 1 states that teachers are professional educators with the primary task of educating, teaching, guiding, directing, train, assess, and evaluate students on early childhood education, formal education, basic education and secondary education. Teacher holds a very important role in the development of curriculum because teachers should look for new ideas in implementing of learning in any curriculum being used.

In addition, Faridah Alawiyah (2013) in his article entitled "The Impact of Implementation of Curriculum 2013 to Teacher" states that the teacher is not ready and hard to change their ways of thinking to the used of curriculum 2013. It was happened because the less optimal training provided by the government. It could not change teachers' mindset. This problem will affect the ability of teachers in teaching the students.

Based on the results of interviews with a fourth grade teacher at the elementary school No. 4 Banyuasri namely Ni Wayan Eka Rippanawati, S.Pd. SD on January 26, it was found that many obstacles in managing the classroom. It is caused by the implications of the implementation of the curriculum 2013 that is suddenly sounded. Teachers faced many problems in constructing lesson plan (RPP) related to the guidance of curriculum 2013. They must integrate variety of subjects into a lesson. Beside that their understanding about scientific approaches was low and they could not apply authentic assessment. In line with that condition, Ahmad (2013) in his article entitled "The Weakness and The Strength of Curriculum 2013" states that, the problem in implementing the curriculum in 2013 are (1) lack of teachers skills to design lesson plans, (2) lack of teachers understanding about the concept of observing, asking, gathering information / tries, reason and communicating, and understanding the scientific approach, (3) Teacher does not know much about authentic assessment and (4) creativity in syllabus developing becomes less. Therefore the implementation of Curriculum 2013 should be considered in an attempt to improve the education system in Indonesia. Within this research, we hope that the teacher's obstacles can be known and we could look for the solution.

Based on the analysis above it is necessary to do research related to the learning ability of teachers to implement the Curriculum 2013 in terms of the preparation of lesson plan (RPP), the 
implementation of learning, assessment and implementation in title "Identifikasi Kemampuan Guru Kelas IV dalam Menerapkan Pembelajaran Tematik Berdasarkan Kurikulum 2013 Semester Genap Tahun Pelajaran 2014/2015 di SD No. 4 Banyuasri". Therefore, the purpose of this research is to describe the IV grade teacher's ability to apply the Thematic learning based on Curriculum 2013 in SD No. 4 Banyuasri in the (semester genap) year 2014/2015 reviewed from lesson plan (RPP) making, learning implementation, and learning assessment implementation.

\section{Research Methods}

Types of research used in this study is qualitative description research about IV grade teacher's ability in implementing learning based on Curriculum 2013. Descriptive research does not give any treatment, manipulation or changing to the free variables but describe the situation as it is. The research place is in SD No. 4 Banyuasri. The research subject is IV grade thematic teacher in SD No. 4 Banyuasri, lesson plans, and assessment paper. Research subject selected using purposive sampling technique.

Data collection methods used is observations, documentations, and interview. Observation method implemented in this research is a passive participant observation. According to Sugiyono (2014: 311), "Participatory observation can be classified into four, namely passive participation, moderate participation, frank and subtle observation, and complete observation". Interview method used in this research is stage interview / free guided namely depth interviews but is guided by the main questions (in Satori, 2011) that given to the informants that is IV grade thematic teacher in SD No. 4 Banyuasri in implementing Curriculum 2013 in terms of lesson plan making, learning implementation and learning assessment implementation. Document study method is a complement of observation and interview method use. According to McMillan and Schumacher (in Satori, 2011) document is a recordings of past events written or printed, can be anecdotal records, letters, diaries, and documents.

Research instruments that used are observation papers, document notes, and interview guidance. Observation paper in this research done by observing teacher's ability in learning implementation and learning assessment implementation based on Curriculum 2013 when learning takes place based on the indicators that are prepared in observation paper. The referred documents are archived lesson plan which is owned by IV grade teacher and the assessment paper. Interview guidelines in this study contain the description of the research outlined in the form of a list of questions so the interview process can run well. The collected data is in the form of a transcript of the interview about teacher's ability in implementing the learning based on the Curriculum 2013 in terms of the preparation of lesson plans, learning implementation, the learning assessment implementation, documentation of lesson plan that the IV grade teachers have, and the value of the variable of preparation of lesson plans, learning implementation, and the implementation of learning assessment were analyzed descriptively.

\section{Finding}

\section{Finding and Discussion}

The result of teacher ability in preparing the lesson plan (RPP) can be seen as follows

Table 1. Lesson plan scores

\begin{tabular}{|c|c|c|c|c|c|}
\hline \multirow{2}{*}{ No } & \multirow{2}{*}{ Teacher Performance Indicators } & \multicolumn{3}{|c|}{ Teacher Performance Scores } & \multirow{2}{*}{ Average } \\
\hline & & 1 & 2 & 3 & \\
\hline 1 & RPP Components & 4 & 4 & 4 & 4 \\
\hline 2 & $\begin{array}{l}\text { Clarity of developing indicators KD-3 and KD-4 } \\
\text { from KI-3 and KI-4 }\end{array}$ & 4 & 4 & 4 & 4 \\
\hline 3 & $\begin{array}{l}\text { The selection and organization of teaching } \\
\text { materials }\end{array}$ & 4 & 4 & 4 & 4 \\
\hline 4 & Clarity of learning steps & 4 & 4 & 4 & 4 \\
\hline 5 & Assessment, remedial and enrichment & 4 & 4 & 4 & 4 \\
\hline 6 & Selection media & 4 & 4 & 4 & 4 \\
\hline \multicolumn{2}{|r|}{ Total of Teacher Performance Scores } & 24 & 24 & 24 & 24 \\
\hline \multicolumn{2}{|r|}{ Total Conversion of Teacher Performance Scores to 100} & 100 & 100 & 100 & 100 \\
\hline
\end{tabular}


scale (Regulation of PAN and RB Ministry No. 16 point

15 of 2009)

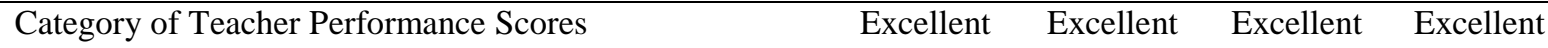

Based on the calculation, the average of total score of teacher performance indicators in designing lesson plan is 24 (from the maximum total score 24). Once converted to a scale of 100 in accordance with the Regulation of PAN and RB Ministry No. 16 year 2009 are in the range of 75 to 100. This shows that the ability of teachers in designing lesson plan (RPP) of Curriculum 2013 an be categorized as excellent.

Data of teacher performance assessment in implementing the learning process based on the curriculum 2013 is generally described in Table 2 .

Table 2. Score and instruction implementation 1

\begin{tabular}{|c|c|c|c|c|c|}
\hline \multirow[t]{2}{*}{ No. } & \multirow[t]{2}{*}{ Teacher Performance Indicators } & \multicolumn{3}{|c|}{$\begin{array}{l}\text { Teacher Performance } \\
\text { Scores }\end{array}$} & \multirow[t]{2}{*}{ Average } \\
\hline & & 1 & 2 & 3 & \\
\hline A. & Preliminary activities & & & & \\
\hline 1. & $\begin{array}{l}\text { Condition class before starting the learning } \\
\text { process }\end{array}$ & 4 & 4 & 3 & 3.7 \\
\hline 2. & $\begin{array}{l}\text { Asking questions about the competency that has } \\
\text { been achieved and related to the competencies } \\
\text { that will be achieved }\end{array}$ & 4 & 4 & 4 & 4 \\
\hline 3. & $\begin{array}{l}\text { Delivering the information about the } \\
\text { competency that will be achieved and its } \\
\text { benefits in everyday life }\end{array}$ & 1 & 4 & 1 & 2 \\
\hline 4. & $\begin{array}{l}\text { Sharing the material and activities that will be } \\
\text { conducted }\end{array}$ & 1 & 1 & 1 & 1 \\
\hline 5. & $\begin{array}{l}\text { Discussing the learning scope and assessment } \\
\text { techniques that will be used }\end{array}$ & 1 & 1 & 1 & 1 \\
\hline B. & Main activities & & & & \\
\hline 6 & Mastering the learning material & 4 & 4 & 4 & 4 \\
\hline 7 & Applying scientific approach effectively & 4 & 4 & 4 & 4 \\
\hline 8. & $\begin{array}{l}\text { Using the learning resources effectively and } \\
\text { efficiently }\end{array}$ & 4 & 4 & 4 & 4 \\
\hline 9. & $\begin{array}{l}\text { Using the learning tools and media effectively } \\
\text { and efficiently, and involving the students }\end{array}$ & 4 & 4 & 4 & 4 \\
\hline 10. & Building students' participation in learning & 4 & 1 & 4 & 3 \\
\hline 11. & $\begin{array}{l}\text { Conducting the learning activity in order to build } \\
\text { positive habit for students. }\end{array}$ & 4 & 4 & 4 & 4 \\
\hline 12. & $\begin{array}{l}\text { Using the right and appropriate language in } \\
\text { learning. }\end{array}$ & 4 & 4 & 4 & 4 \\
\hline 13. & Using the time allotment that has been planned & 1 & 1 & 1 & 1 \\
\hline C. & Post Activities & & & & \\
\hline 14. & $\begin{array}{l}\text { Conducting the reflection or making summary } \\
\text { which involves the students }\end{array}$ & 4 & 4 & 4 & 4 \\
\hline 15. & $\begin{array}{l}\text { Providing some feedbacks based on the process } \\
\text { and the learning result. }\end{array}$ & 4 & 4 & 4 & 4 \\
\hline 16. & Providing the individual or group a task & 1 & 1 & 4 & 2 \\
\hline 17. & $\begin{array}{l}\text { Giving information about the learning plan for } \\
\text { next meeting }\end{array}$ & 1 & 1 & 1 & 1 \\
\hline \multicolumn{2}{|r|}{ Total scores of teacher's performance } & 50 & 50 & 52 & 50.7 \\
\hline \multicolumn{2}{|c|}{$\begin{array}{l}\text { Total Conversion of Teacher Performance Scores to } 100 \\
\text { scale (Regulation of PAN and RB Ministry No. } 16 \text { point } \\
15 \text { of 2009) }\end{array}$} & 73.52 & 73.52 & 76.47 & 74.55 \\
\hline \multicolumn{2}{|c|}{ Teacher's performance category } & Good & Good & Good & Good \\
\hline
\end{tabular}


Based on the result from calculation, the total average of the teacher's performance score in conducting the learning activity is 50.7 (from the total maximum score is 68). After it is converted to the 100 scale based on Regulation of PAN and RB Ministry. No. 16 in 2009, it is in the range of 51 to 76. It shows that the ability of the teacher in the fourth grade of elementary school in conducting the learning activity based on the use of curriculum 2013 can be categorized good.

The table below is shown the result of the teacher's performance in using the assessment based on curriculum 2013.

Table 3. Score and instruction implementation 2

\begin{tabular}{|c|c|c|c|c|}
\hline \multirow[t]{2}{*}{ Teacher's performance indicators } & \multicolumn{3}{|c|}{$\begin{array}{c}\text { Teacher's } \\
\text { performance score }\end{array}$} & \multirow[t]{2}{*}{ Average } \\
\hline & 1 & 2 & 3 & \\
\hline Assessment & & & & \\
\hline $\begin{array}{l}\text { a. Assessing students' spiritual attitude } \\
\text { with non test method }\end{array}$ & 4 & 1 & 1 & 2 \\
\hline $\begin{array}{l}\text { b. Assessing students' social attitude } \\
\text { with non test method }\end{array}$ & 4 & 1 & 1 & 2 \\
\hline $\begin{array}{l}\text { c. Assessing students' knowledge with } \\
\text { test method }\end{array}$ & 4 & 4 & 4 & 4 \\
\hline $\begin{array}{l}\text { d. Assessing students' skill with non test } \\
\text { method }\end{array}$ & 4 & 4 & 4 & 4 \\
\hline Total of Teacher Performance Scores & 16 & 10 & 10 & 12 \\
\hline $\begin{array}{l}\text { Total Conversion of Teacher Performance } \\
\text { Scores to } 100 \text { scale (regulation of PAN and RB } \\
\text { Ministry No. } 16 \text { point } 15 \text { of } 2009 \text { ) }\end{array}$ & 100 & 62.5 & 62.5 & 75 \\
\hline Category of Teacher Performance Scores & Good & Good & Good & Good \\
\hline
\end{tabular}

Based on the calculation, the total score of the performance indicators of teachers in conducting assessment is 12 (out of a total maximum value is 16). After converted into scale of 100 that accordance with Permenneg PAN and Rb no 16 th 2009 are in the range of 51 to 76 . This shows that the ability of grade 4 teachers at SD No 4 Banyuasri in conducting assessment based on curriculum 2013 can be categorized good.

\section{Discussion}

The first step in learning is planning the lesson that is realized with drafting the lesson plan (RPP). Lesson plan is essentially a short-term planning to predict or project what to do in learning. Thus lesson plan is an effort to estimate the action in learning activities.

Based on the result of the study, the ability of teachers in designing lesson plan is excellent. The findings obtained from the average total value of the teacher's performance in designing lesson plan is 24 (from total maximum value 24), after converted into a scale of 100 in accordance with the Regulation of PAN and RB Ministry no 16 in 2009, which are in range of 76 to 100. This shows that the ability of teacher in designing lesson plan is categorized excellent.

In this study, the aspects that are assessed in constructing the lesson plan are completeness of rpp lesson plan components, clarity of development indicator KD-3 and KD-4 from KI-3 and KI-4, selection and organization of teaching materials, the clarity of the steps in conducting assessment, remedial and enrichment, and selection of resources and instructional media. All aspects have been prepared according to the standard in preparing lesson plan based on Regulation of Education Ministry No 103 in 2014. Based on 6 aspects that have been assessed at three lesson plan that had been developed by the teacher, all aspects are qualified in lesson plan preparation accordance with Regulation of Education Ministry no 103 th 2014. Based on interviews with Ni Wayan Eka Ripnawati, S.Pd., the fourth grade's teacher of SD No. 4 Banyuasri, teachers did not have serious problems in preparing lesson plan because they have attended teacher training about the implementation of curriculum 2013. Teachers have followed three times in training about the procedures in preparing lesson plan based on curriculum 2013 which are accommodated by 
Disdikpora and LPMP through education government committee at Bali Beach Hotel on July 2013 and at Nusa Dua on June 2014. From that training, teachers got much guidance from other teacher and the experts. The teacher also got many experiences and detail information about curriculum 2013 and the way how to prepare the lesson plan.

In that training, teachers are also expected to continue in following some developments regarding the curriculum such as improvement of Regulation of Education Ministry 2013 on the implementation of Curriculum 2013. In addition, teachers also revealed that compiled lesson plans has been supervised by the supervisor of the Bali Provincial Education Department and has been certified by the principal, so the validity of the quality of lesson plans prepared by teachers can be informed has achieved the preparation standard of the lesson plans in accordance with Regulation of Education Ministry No. 103 in 2014. It is also supported by the results of a questionnaire given by the supervisor of Klungkung as representative of Bali Province Education Department, teachers recognize scored very good about the knowledge of lesson plans' arrangement Curriculum 2013 by referring Regulation of Education Ministry No. 103 in 2014.

Based on the analysis and interviews above, it is clear that teachers have understood the lesson plan based Curriculum 2013 well after some training. It means that teachers' understanding gained from experience related to the training of arrangement Curriculum 2013 is directly proportional to the quality of the lesson plan prepared by the teacher. So it can be informed that training is accommodated by the Education Government Office Bali can optimize teachers' understanding related to the preparation of lesson plan Curriculum 2013.

Many things can affect the ability of teachers in designing lesson plans such as teaching experience, tenacity and effort to learn a teacher (self-development), teacher education, and others. Related to teacher education, as well as observation and documentation study found that teacher education qualification which is the subject of research is bachelor in public universities (PTN). Although the education level doesn't affects $100 \%$ the level of professionalism of the teacher, but there is also the effect of studies experience when implementing the previous lectures and business development itself. Therefore, teachers should keep doing self-development so that it can prepare the learning of lesson plan consistently.

Based on the research that has been carried out for 2 weeks with assessing specifically for the process of teaching and learning activity conducted by teachers, they have implemented the learning activities such as pre-activity, main activity, and post-actvity properly appropriate with standard of Regulation of Education Ministry No. 103 in 2014. The findings were derived from observations that have been made that teachers earned an average total value of the performance of teachers in implementing the learning is 51 (out of a total maximum value of 68). Once converted to a scale of 100 appropriate with theRegulation of PAN and RB Ministry No. 16 in 2009 showed 74, 99 are in the range of 51 to 76 according to the Table 3.8. In more detail on the pre-activities for teachers to get an average value of 11.7 of the total value of 20 , main activities of teachers earned an average value of 28 of the total 32, and post activity for teachers to get an average value of 11 of the total 16 . The problems that occurred and related to the implementation of learning in the classroom that the teacher was found still inappropriate with the implementing learning plans that have been designed in the lesson plans.

Based on interviews with Ni Wayan Eka Ripnawati, S.Pd., thefourth grade's teacher of SD No. 4 Banyuasri, as for some reasons expressed by the teacher that the learning is not conducted according to lesson plan partly due to the initial knowledge of students is relatively low, the subject matter of solid having to integrate a variety of subjects, time allotment, and scientific approach requiring extra time in learning. After the further research, the key problems is also on the lack of teachers' understanding of the stages of learning activities in accordance with Regulation of Education Ministry No. 103 in 2014 based on time allotment that has been planned in the lesson plan (RPP).

The biggest problem that was experienced by the teachers in teaching was managing the time allotment. It was not only caused by the inability of teachers in managing the time, but there were some external factors that influenced it. Based on the interviews from the teacher, the incompatibility between learning activities that have been implemented and the time allocation was caused by several factors, namely the teacher could not conduct the lesson on time because they had to ask the students to clean the classroom, and there were some announcement which must be shared in the class. That condition was same with the result of observation that was conducted during teaching and learning 
process done in the class.

Teachers are the important component in the formal education system which directly related to the students. The success of the learning process in achieving the learning objectives is determined by the teacher. Teachers should be able to organize the time well in order to be a professional teacher. Furthermore Satori (in Riandi, 2012) stated that the teachers' activities made the role as manager in learning process. It means that they had important role in planning, implementing and evaluating the teaching and learning process. The finding above indicated that the teacher's role as manager of learning was not running well, it could be seen from the mismatches between the implementation of learning and the time allotment.

The results of the observation stated that there were some problems found by teachers when implementing the learning activity in the classroom. In the preliminary activities the teacher did not conduct apperception stage, did not share the competency that must be achieved and its benefit in our life, and did not tell the assessment that was used in the teaching and learning process activities. Besides that, they also faced some problems in improving students' participation and in managing time allotment in whilst activity. In addition, in the post activity they could not give a reflection about learning process and plan for the next activity.

The government regulation number 74 in 2008 about teacher stated that the teacher is a professional educator with a primary task of educating, teaching, guiding, directing, train, assess, and evaluate students on early childhood education, formal education, primary education and secondary education. Furthermore, teachers should have four competencies, namely professional competency, pedagogical competency, personality competency and social competency. Based on the observations and interviews, teachers did not understand the function of these four competencies in depth that influenced the implementation of learning in the classroom. The learning activity in the classroom was often mismatched with the planning that has been compiled on the lesson plan (RPP).

The finding shows that the teachers have used appropriate assessment. It can be seen from the total score of teachers performance in applying assessment was 11 (from maximum total score 16). After converted into scale 100 accordance with the Regulation of PAN and RB Ministry in 2009, it can be categorized as good. It shows that the teachers are still facing problems in implementing assessment based on curriculum 2013. The teachers must improve and control the student's attitude as one aspect that must be assessed. But in fact, they did not assess and control the student's attitude.

Kurniasih and Berlin (2014) stated that an observation technique is a technique that is used to assess performances sustainably by using our five senses based on the indicators stated in the criteria. So that, the teacher must assess the students' attitude sustainably. But in fact, the teachers did not apply holistic attitude assessment. It was seen from the mismatches of the assessment planning with the implementation in the classroom. As professional teachers, they are obliged to do some improvements, self development, enrich knowledge related to the implementation of attitude assessment so that curriculum 2013 can be applied optimally.

Based on interviews and findings from the observation about teachers' effort in applying assessment, they had high commitment in developing their competency in applying curriculum 2013 so that so that the learning activities can be optimized in accordance with the standards Regulation of Education Ministry No. 103 in 2014. It was in line with Rusman (2012) who said that a professional teacher must have pedagogy competency that will be used to manage the class and improve students' competency especially attitude aspect.

\section{Conclusion}

Based on the description above, it can be concluded that the lesson plan that was designed by the fourth grade teacher at SD No.4 Banyuasri was qualified excellent. It can be seen from total teacher performance score was 24 (the total maximum score was 24) which was in range of 76 to 100 after converted to scale of 100 in accordance with Regulation of PAN and RB Ministry No.16 in 2009. On the other hand, the implementation of thematic lessons that was conducted by fourth grade teachers at SD No.4 Banyuasri was categorized good. It can be seen from the total score of teacher performance was 50,7 (the total maximum score was 68) which are in the range of 76 to 100 after converted to a scale of 100 in accordance with Regulation of PAN and RB Ministry No.16.

The implementation of assessment that was conducted by fourth grade teacher at SD No. 4 Banyuasri can be categorized good which total teacher performance score was 12 (total maximum 
score was 16) which are in the range of 76 to 100 after converted to a scale of 100 in accordance with Regulation of PAN and RB Ministry No. 16 in 2009.

\section{References}

Ahmad, Jumal. (2013). Keunggulan dan Kelemahan Kurikulum 2013. (The Strengths and Weaknesses of Curriculum 2013). Available at http://ahmadbinhanbal.wordpress.com/perihalkeunggulandankelemahankurikulum2013 (Retrieved on 5th January 2015).

Asyhar, Beni. (2013). Peran dan Fungsi Kurikulum. (The roles and Functions of Curriculum) Available at https://asyharbeni.files.wordpress.com/2013/09/peran-dan-fungsikurikulum.pdf.

Kurniasih, Imas dan Berlin Sani. (2014). Implementasi Kurikulum 2013: Konsep dan Penerapan. (The implementation of Curriculum 2013: Concept and Implementation). Surabaya: Kata Pena.

Sanjaya, Wina. (2005). Pembelajaran dalam Menerapkan Kurikulum Berbasis Kompetensi. (The Instructions in Implementing Competency-based Curriculum). Jakarta: Kencana.

Peraturan Menteri Pendidikan dan Kebudayaan No. 103 Tahun 2014 tentang Pembelajaran Pada Pendidikan Dasar dan Pendidikan Menengah. 2014.(Regulation of Education and Culture Ministry No. 103 Year 2014 about Instructions on Elemetary and Secondary Education). Jakarta: Kementerian Pendidikan dan Kebudayaan.

Peraturan Menteri Pendidikan dan Kebudayaan No. 104 tahun 2014 tentang Penilaian Hasil Belajar oleh Pendidik Pada Pendidikan Dasar dan Pendidikan Menengah. 2014. (Regulation of Education and Culture Ministry No. 104 Year 2014 about Learning Assessment by Teachers of Elementary and Secondary Education). Jakarta: Kementerian Pendidikan dan Kebudayaan.

Peraturan Pemerintah. 2008. PP No. 74 tahun 2008 Tentang Guru.( Government Regulation Year 2008 No 74 about Teachers). Jakarta: Mendiknas.

Riandi. (2012). Sistem Pembinaan Profesionalisme Guru IPA. The system of Profesisonal Development of Science Teachers). Available at http://file.upi.edu (Retrieved on 28th April 2015).

Satori, Djam'an dan Aan Komariah. (2011). Metodologi Penelitian Kualitatif. (Qualitative Research Methodology). Bandung: Alfabeta.

Sugiyono. (2007). Metode Penelitian Administrasi. (Administrative Research Methods). Bandung: alfabeta. 